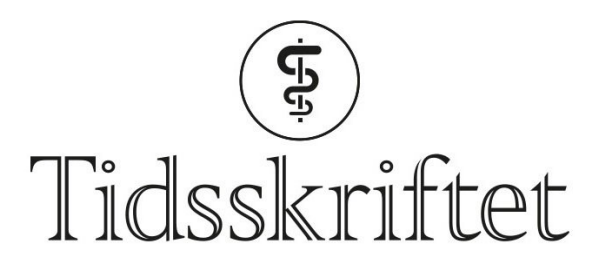

DEN NORSKE LEGEFORENING

\title{
Fysisk aktivitet og hjertesykdom i lavinntektsland
}

FRA ANDRE TIDSSKRIFTER

MATILDE RISOPATRON BERG

Sykehuset Innlandet, Hamar

Fysisk aktivitet reduserer risikoen for død og alvorlig hjerte- og karsykdom også når aktiviteten er knyttet til arbeid. Dette er uavhengig av landets inntektsnivå.

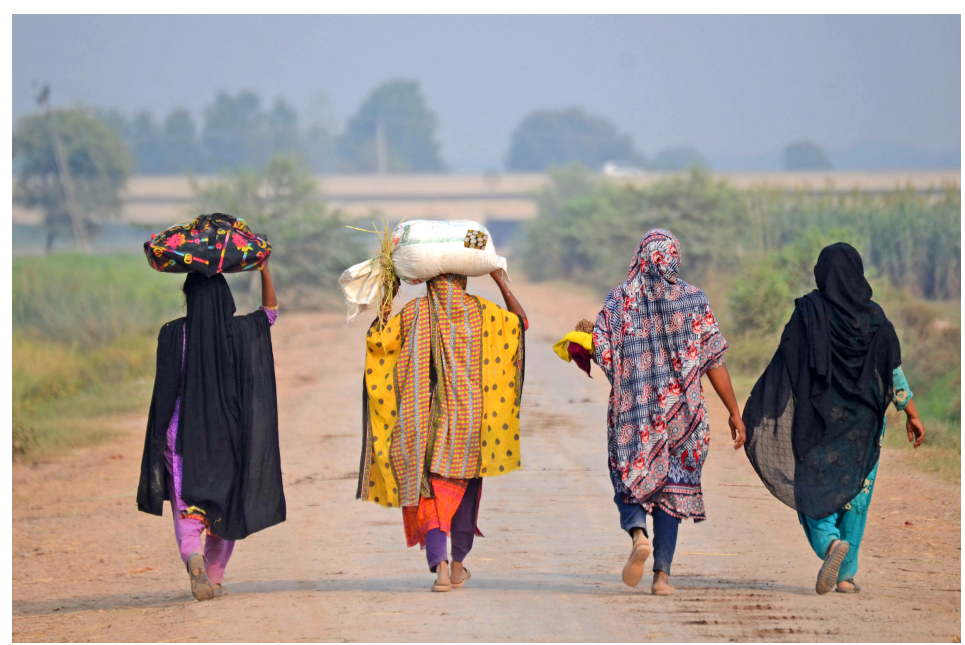

Illustrasjonsfoto: Sipausa/Pacific Press/NTB Scanpix

I en prospektiv kohortstudie med 130 ooo personer fra 17 land ville man unders $\varnothing$ ke om fysisk aktivitet i lavinntektsland beskytter mot hjerte- og karsykdom og død i like stor grad som i høyinntektsland. I lavinntektsland er fysisk aktivitet oftest relatert til arbeid, husarbeid eller transport, mens fysisk aktivitet i høyinntektsland vanligvis er en fritidsaktivitet.

Deltagere med kjent hjerte- og karsykdom ved inklusjonstidspunktet ble ekskludert. Etter gjennomsnittlig 6,9 år var rundt 5300 personer døde, hvorav en femdel pga. hjerte- og karsykdom. Om lag 4 ooo deltagere hadde hatt hjerteinfarkt eller hjerneslag, og nesten 400 hadde utviklet hjertesvikt.

Personer som oppga å ha vært fysisk aktive i minst 150 minutter per uke, hadde lavere risiko for død (hasardratio o,72; $95 \%$ KI o,67-0,77) og for alvorlig hjerte- og karsykdom (hasardratio o,80; 95 \% KI o,74-o,86) enn dem med lavere aktivitetsnivå. Manglende fysisk aktivitet kan forklare $8 \%$ av alle dødsfall og 4,6\% av tilfellene med alvorlig hjerte- og karsykdom. Jo mer fysisk aktive deltagerne var, jo lavere var risikoen for $\mathrm{d} ø \mathrm{~d}$ og alvorlig hjerte- og karsykdom. Den beskyttende effekten var uavhengig av om den fysiske aktiviteten var relatert til arbeid, 
husarbeid, transport eller til fritid. Effekten var også uavhengig av landets inntektsnivå, selv om total fysisk aktivitet var høyest i høyinntektsland.

Resultatene tyder på at fysisk aktivitet forebygger hjerte- og karsykdom og død i alle land, uavhengig av landets inntektsnivå.

\section{LITTERATUR:}

1. Lear SA, Hu W, Rangarajan S et al. The effect of physical activity on mortality and cardiovascular disease in 130 ooo people from 17 high-income, middle-income, and low-income countries: the PURE study. Lancet 2017; So140-6736(17)31634-3. [PubMed]

Publisert: 8. januar 2018. Tidsskr Nor Legeforen. DOI: 10.4045/tidsskr.17.0986

(C) Tidsskrift for Den norske legeforening 2020. Lastet ned fra tidsskriftet.no 